\title{
Re ections on a privilege
}

\author{
Becoming part of the course \\ by a collaboration on Blackboard
}

by Kara L. Giles

I n a January 2002 article in CERL News, ${ }^{1}$ Christopher Cox offered a challenge coupled with a road map. He encouraged his readers to "become a part of the course" by integrating library instruction into Blackboard courses taught by other faculty members. Cox described various user management features on this widely used course management software package and gave tips on how to achieve integration. During the spring semester of 2003, I decided to accept his challenge and became part of a senior-level, capstone history course involving the use of Blackboard at Dominican University. These are reflections on my librarian/faculty collaboration using Blackboard.

\section{Establishing a faculty relationship}

Cox noted that his integration strategies assumed a "good working relationship with and prior permission from the faculty member teaching the course." In the fall of 2002, I was a first-year, full-time faculty member in the library department. Dominican is a small, midwestern university with less than 100 full-time faculty members. Newbies stand out. I was fortunate to meet others similarly situated at our university president's new faculty dinner. One of my fellow newbies asked me to guest lecture in her fall history courses, and an excellent working relationship quickly followed. Unlike the experiences of some librarians at other colleges, ${ }^{2}$ I have consistently been treated as "real" faculty by my colleagues at Dominican and have an advantage in establishing faculty relationships that others may find hard to duplicate.

Although Dominican has widely embraced Blackboard 5 as an instructional tool, it restricts use (and support) to faculty members who have attended a four-hour workshop or who have previously hosted a Blackboard site. I decided I wanted to use Blackboard for library instruction and attended the required workshop in December 2002. At the workshop I noticed the same new faculty member, and I mentioned that I was interested in doing a collaborative Blackboard project with her for one of her spring 2003 history courses. ${ }^{3}$ She readily agreed, and we sketched out a rough plan for the mechanics of our collaboration.

\section{Access level decision}

At Dominican, the Blackboard administrator has enabled faculty course creators to grant various levels of access to course users. The creator of a course may enroll a user and grant them rights as a student, instructor,

\section{About the author}

Kara L. Giles is the systems librarian for Dominican University in River Forest, Illinois, e-mail: kgiles@dom.edu 
teacher's assistant, grader, or course builder. Cox gave detailed explanations for each level of participation in his article, which I will not repeat here. Although Cox promoted being added at the instructor level (with control over all aspects of a course, including grades), I decided that requesting to be added as a course builder would be the easier sell. A course builder is able to add content to a course, but cannot access students' online grades. ${ }^{4}$ This turned out to be the key factor in convincing the history professor to let me join her Blackboard course. I found that the course builder level provided me with exactly the type of access and control that I wanted.

As a course builder I was able to add my faculty profile and contact information, start a forum on the discussion boards, upload course documents, and initiate or respond to a threaded list on the discussion board. I also was able to privately e-mail the members of the class.

\section{Course development}

The course was a senior-level, capstone history seminar. I attended the entire three-hour first meeting of the class, and my role was described and included on the syllabus. All students had used Blackboard and were familiar with its functions. My role as research "coach" on Blackboard was stressed. The professor assured the class that I would not have access to their grades and allowed me to partake in their classroom discussion. There were several advantages to my staying in the classroom for the entire first meeting: reinforcement that I was more than a one-shot guest lecturer, an opportunity to interact on an individual basis with the students, and a demonstration that I considered myself a member of their class in more than the cyber sense. I believe this was critical to establishing a rapport for the students to feel comfortable trusting me with their research questions on Blackboard during their capstone course.

My next meeting with the class involved delivering a traditional library instruction session in which I emphasized print and online statistical sources for historical research. I thought this would be an advanced research topic they may not have encountered before. I told them I was available on Blackboard for their questions after my presentation, and I uploaded a guide so that it would be permanently available during the course. I envisioned my continuing role to be that of a type of research chauffeur, waiting to be told where to take students down a research path. This soon changed.

\section{Changes from within-How it changed me}

Because I had more than a one-shot contact with these students, I felt comfortable becoming proactive whenever I encountered "my" students in the library. In fact, I felt compelled to really look at and interact with these students, and not just exchange pleasantries. This was a considerable personality change. I am like most librarians and have a somewhat introverted personality. ${ }^{5}$ I usually overcome it with effort. Becoming "part of the course" greased the path to surmounting my initial fear of embarrassing someone who has not asked for my help.

One day I noticed one of my students was struggling at the computer, and I felt comfortable asking if she was "finding what she needed." She was eager to talk with me and easily told me she was having trouble with her research project. Because I was familiar with the course and its assignments, I was able to quickly determine that she didn't know how to use the online catalog effectively - a skill that I thought would have been learned in her freshman year. Through Blackboard, I was able to quickly determine that most of the class needed a back-to-basics library instruction class. The professor quickly made room on the syllabus for me to teach a "research tune-up" class.

My involvement in the class also required me to become familiar with the articles and Web sites that the professor posted to Blackboard. I was able to expand my knowledge base in this discipline and have used the information to answer questions that I received at the reference desk from other students at the university.

Like most librarians, I am exposed to "infowhelm," that is, a vast array of information distributed on a daily basis in multiple formats, such as newspapers, radio broadcasts, Web sites, blogs, journals, books, films, and TV. I must selectively filter what I choose to listen to or read, or become overwhelmed. I found myself tuning my attention antenna to topics that would be of concern to this Blackboard class. When I thought a topic 
might interest the students, I asked the professor if I could post the information to the course. After a while, I was allowed to post content on my own, and a discussion thread invariably followed.

\section{Class reflections}

The professor said that both she and her students welcomed my presence and contributions on Blackboard and felt much more comfortable in asking for research help in this course than in others.

\section{Privilege}

It was a privilege to be allowed to become a course builder. I use this term because I became more than an information literacy cyber-tutor. The right to add course content to another faculty's senior-level, capstone course is a privilege. The dynamics and synergies of the class, both on Blackboard and in the real class environment, enabled me to become immersed in the course and take a broader role. It was peculiar to this class, and I do not expect to be accorded similar privileges in other collaborative Blackboard courses, unless I have earned it.

\section{Propagation}

In a librarian's world, when we find a good thing, two things will occur. We will invariably be asked a question about it within a week, and we want to share it with our colleagues. I have been asked to present a seminar to the rest of Dominican's faculty to share my experiences as a collaborator on Blackboard. Because I will show an archived copy of the course that will display students' names, I first obtained the approval of our Institutional Review Board (IRB), which was granted only because I would be showing it exclusively to Dominican's faculty.

I hope this article will encourage you to also become a collaborator. In doing research for this article, I found that a Google search for "librarian faculty collaboration Blackboard" produced more than 2,500 sites. A journal search in the Library Literature $\&$ Information database produced 33 references. Almost all of these articles and Web sites relate to tips and techniques on how to incorporate information literacy into a Blackboard course. Clearly this has become a hot topic in our profession.

\section{Conclusion}

Becoming a collaborator on Blackboard, or other courseware, has many advantages for you as a librarian, the professor, and your students. If you succeed in getting added to a Blackboard course, it is a right that must be exercised judiciously. The potential for disaster is great because the exposure to your library department's reputation is great. Unanswered e-mail questions from students will stand out in a discussion thread on Blackboard. Without a doubt, becoming "part of the course" is a deep and semester-long commitment. Decisions about which course, and how deep an involvement, must be examined carefully based on your own subject expertise and concurrent commitments.

If you are thinking about publishing your results, I recommend obtaining prior approval from your own IRB. I can only hope you derive as much satisfaction from your Blackboard collaboration as I did.

\section{Notes}

1. Christopher N. Cox, "Becoming Part of the Course: Using Blackboard to Extend One-Shot Library Instruction," CERL News 63, no. 1 (2002): 11-13, 39.

2. Kenneth E. Carpenter, "The LibrarianScholar: Enmity Between Librarians and Teaching Faculty," Journal of Academic Librarianship 23 (September 1997): 398-401. See also, Irene Doskatsch, "Perceptions And Perplexities of the Faculty-Librarian Partnership: An Australian Perspective," Reference Services Review 31 No. 2 (2003): 111-121.

3. Librarians have tenure-tract faculty status at Dominican University. It is sometimes confusing for faculty and students to affiliate me with a particular school because Dominican also has a Graduate School of Library and Information Science (GSLIS). I am frequently thought of as being affiliated with and having more concern about the GSLIS School. In fact, the Library Department is under the College of Arts and Sciences.

The Course Builder role has access to limited areas of the course's Control Panel. A Course Builder has access to the Content Areas, User Management, Course Tools, and

(continued on page 268) 
though less than two years old, SPARC Europe already has more than 80 members in 14 European countries. ${ }^{11}$ By coming together, members can amplify their voices and help to create change. ${ }^{12}$

\section{Notes}

1. www.parliament.uk/parliamentary_ committees/science_and_technology_committee /scitech111203a.cfm. Transcripts of the oral evidence can be found at www.publications. parliament.uk/pa/cm/cmsctech.htm.

2. www.zim.mpg.de/openaccess-berlin /berlindeclaration.html.

3. www.wellcome.ac.uk/en/1/awtvispolpub.html.

4. www.soros.org/openaccess.

5. Details of the various Institutional Repository software can be found at GNU Eprints: software.eprints.org/, CDSWare: cdsware.cern. ch/, Arno: www.uba.uva.nl/arno.

6. DARE: www.surf.nl/en/themas/index2. php?oid=7, SHERPA: www.sherpa.ac.uk/.

7. www.doaj.org.

8. www.biomedcentral.com.

9. David C. Prosser, "From Here to There: A Proposed Mechanism for Transforming Journals from Closed to Open Access,"
Learned Publishing, vol. 16 (2003), pp. 16366. (An earlier version is available at www.arl. org/sparc/core/index.asp?page=g29) .

10. Oxford University Press: www3.oup.co.uk/ nar/special/14/default.html, Company of Biologists: www.biologists.com/openaccess.html, Society of Experimental Biology (Journal of Experimental Botany): www.jisc.ac.uk/index.cfm?name=news_ openaccess_0304.

11. www.sparceurope.org/, www.arl.org/sparc.

12. www.arl.org/create/.

("Reflections..." continued from page 263) Course Options areas of the Control Panel, but not to the Assessment section of the Control Panel or to the Manage Groups functions in the User Management section. Therefore, a user with the Course Builder role would not have access to the Online Gradebook. If a course is Unavailable to students, the Course Builder may still access the course Web site.

5. Renee Vaillancourt McGrath, "Meet New People and Make Friends," Public Libraries 42, no. 4 (July/August 2003): 210. See also, John Agada,"Profiling Librarians with the Myers-Briggs Type Indicator," Education for Information 16, no. 1 (March 1998): 57-58. 